MANAGEMENT

RECEIVED:

20 July 2021

ACCEPTED:

20 August 2021

RELEASED:

20 October 2021
UDC 005.42-024.61:305

DOI 10.26661/2522-1566/2021-3/17-02

\title{
COMMUNAL SUPPORT, WORK ATTITUDE, STRESS AND JOB OUTCOME ACROSS GENDER
}

\author{
Sohail Imran Khan \\ Lebanese French University, \\ Erbil - Iraq \\ ORCID ID: 0000-0002-4629-2788
}

*Corresponding author email: sohailkhan@lfu.edu.krd

\begin{abstract}
Studies related to communal support, work attitude, stress and job outcome have been done individually in the past. But very less rather no attention was given to study the interrelation between them specially with reference to gender. The Purpose of the study is to explore the difference between male and female IT employees on four variables i.e., communal support, work attitude, stress and job outcome. These four variables were further divided into sub variables. communal support (supervisory support and team support), work attitude (organization commitment and job satisfaction), stress (role ambiguity, role conflict and work overload) and job outcome (turnover intention). Methodology: For the study, 138 IT employees were the participants for the study. The survey data was analyzed using SPSS software to draw a meaningful conclusion. 4 Hypotheses were framed. These hypotheses were partially accepted and rejected. The findings include that female enjoy a higher degree of supervisory support and role ambiguity. On the other hand, team support, organizational commitment, job satisfaction, role conflict, work overload and turnover intention were found to have no significant difference in gender.
\end{abstract}

Keywords: supervisory support, team support, organization commitment, job satisfaction, role ambiguity, role conflict, work overload and turnover intention.

JEL Classification: I24, I31, J28, L81.

\section{INTRODUCTION}

A report published in "The Economic Times" Feb 01 (2020), reveals that the Indian nation has become $\$ 3$ trillion economy in 2019. The report also highlighted that the per capital income of Indians is expected to rise by 2025, as India will be one of the biggest and largest consumer markets by the mid $-21^{\text {st }}$ century. In the list provided for fastest growing companies, apart from financial services, Transport, Ecommerce, Technology, Agriculture, Energy, Health, Construction, etc. many IT/IT enabled companies and BPO were also listed. This clearly indicates that India's IT sector will grow very fast.

India is always a hotspot for outsourcing because it offers ample advantage to the companies. These advantages include cost effective, quality of work, technological efficiency, huge amount of workforce, good communication skills, low labor cost and time zone advantage. More than $80 \%$ of the US and European companies prefer the Indian market for outsourcing (Sarkar and 
Khan, S. (2021), “Communal support, work attitude, stress and job outcome across gender", Management and entrepreneurship: trends of development, 3(17), pp.18-26. Available at: https://doi.org/10.26661/2522-1566/2021-3/1702.

Reddy, 2006). According to CBRE survey in 2017 , over $75 \%$ of MNC's give preference to India for outsourcing. The survey also revealed that, Banglore, Mumbai and Delhi NCR are the preferred destination for outsourcing. Since the IT sector will further grow in the years to come, IT employees will have extra burden of work which may lead to stress and other job issues.

According to NASSCOM report (2018) cited by Raghuram P. et. al., (2018)., direct employees working in IT-BPM industry rose to 3.97 million. It was also revealed that there are a greater number of female employees then men specially at the entry level. Also, they are more qualified as compared to male employees.

India is a country wherein, mostly jobs are dominated by male. Most societies are run by male and major role is also played by male only. Sectors like Steel, textile, and other manufacturing units, jobs are occupied by men. This could be due to more physical work involved. However, when it comes to service industries, again it is mostly occupied by men. When it specifically comes to IT industry, men in not far behind. However, report from NASSCOM (2018) reveals to occupy more job by female then male. The second reason for male to occupy more jobs is the gender gap. On every 100 boys there are only 93 girls. Women include $48 \%$ of the total population in India. This indicates a gap between male and female.

Therefore, it would be interesting to know that is there any favorable attitude for the recruiting person towards the female. Do they get any hiring support? What will be the difference of work attitude between a male and female employee? How these female employees deal with the stress as compared to their male counterparts. Lastly it will be interesting to know the work outcome of male and female employees.

\section{LITERATURE REVIEW}

Zainul et. al., (2020) conducted a survey on 250 employees working in service sector in Malaysia. They concluded that social and communal support specially from supervisor and family members significantly affect the outcome of the job. Narayan (2014) wanted to know the organizational role stress in relationship with social support of industrial employees. Researcher collected a sample from 100 employees from Tamil Nadu and concluded that a positive and significant correlation exists between organizational role stress and social support. Hindes and Andrews (2011) investigated the influence of gender on the supervisory relationship and found that male supervisor show less relationship focus than the female supervisors. They also opined that gender impacts the transparency and association one encounters in supervision. And also, male supervisors rate speculative supervisees all the more contrarily when the supervisee is portrayed as female than when the supervisee is male. Sell, Griffith and Wilson (1998) concluded that there is no difference between gender and support from team. Both men and women get equal support from their team irrespective of the gender of the immediate boss.

Gibbons, Wilson and Rufener (2006) investigated on gender role attitudes which includes machismo and attitudes towards work adaptation. They opined that obviously men show more machismo but they lack in attitude towards adaptation. Female have better attitude towards adaptation. Sabastian (2013), interviewed 45 female and 45 male students to know the gender difference in the attitude towards their work and found no significant difference between the gender and work attitude. Kokubun and Yasui (2021), opined that male employee have higher organization commitment then the female employees, this may be because male employees prefer to work with higher autonomy and well-defined roles than co-worker's support. Many studies related to Job satisfaction has been done previously. Studies related to Job Satisfaction and gender were also carried in past. The results were mixed in nature. Few studies show male have higher JS than female and vice versa. There were studies which also concluded that there exists no significant difference in gender and JS (Andrade, Westover and Peterson, 2019).

Dhanalakshmi, Kathiravan and Muthukumar (2019) conducted a study to know the impact of work stress on employee performance in BPO sector. Their examination has shown high attrition 
rates, reduction in efficiency, incapacitated leaves, low satisfaction, bad quality services and products, low communication and clashes are the vital results in work stress. Some of the outcomes of work stress while nature of work, the work environment, work schedules \& resources and equipment have been found as major factors contributing to work stress. Prathyusha, Durgaprasad and Reddy (2015) found that there exist moderate to high level of professional life stress among the IT professional in Hydrabad. They interviewed 80 male and 70 female IT employees in the age range of 22 to 42 years. However, stress between male and female employees, they do not find and significant difference. Thomas, Krishna and Kumar (2019), conducted a cross sectional study in Madhapur area of Hydrabad among IT professional. In their survey, 286 were males and 114 were female employees. They concluded that females were more stressed than male colleagues. They further concluded that out of 400 employees, 181 employees were having low stress, 134 employees have moderate stress and 85 were having high level of stress. Role ambiguity and Role conflict have a direct relation on gender (Boles, Wood and Johnson, 2003). Anitei, Chraif and Ionita, (2015), conducted a survey on 40 employees of a multinational company in Bucharest. The result proves to have a positive relation between workload and burnout. There is likewise huge contrast among male and female in workload and burnout, which implies females are portrayed by essentially higher level of workload and burnout than male.

Khalid et. al (2009) tried to examine the relation between OCBs and turnover intention. 557 responddent were selected for the study. They revealed that gender moderates the relationship between turnover intention and helping behavior and this relationship was stronger for female employees as compared to male employees. Huwang and Kim (2017), found a significant negative correlation between male gender role conflict and job satisfaction. Further, a positive correlation was also found between male gender role conflict and turnover intention. They concluded that to build work fulfillment and reduction the turnover goal of men in nursing, measures to lessen sexual gender job struggle are required.

$\mathbf{H}_{1}$ : There is a significant difference between male and female employees of IT sector on communal support i.e., supervisory support and team support.

$\mathbf{H}_{2}$ : Work attitude i.e., organizational commitment and job satisfaction of male is higher than the female IT employees.

$\mathbf{H}_{3}$ : There is a significant difference between male and female employees of IT sector on stress i.e., role ambiguity, role conflict and work overload.

$\mathbf{H}_{4}$ : Job outcome i.e., turnover intention of female is higher than the male IT employees.

\section{PAPER OBJECTIVE}

To explore the difference between male and female IT employees on communal support, work attitude, stress and job outcome. In the light of above discussed literature, four hypotheses were framed.

\section{METHODOLOGY}

For the present study primary data was collected from IT employees of Nagpur Region (Maharashtra), India. Secondary information was collected from journals, books, website etc. For this study data was collected using structured questionnaire. A total of 138 employees were selected randomly. Four variables were used for this study. These four variables are communal support, work attitude, stress and job outcome. These four variables were further having sub variables. These sub variables were actually used for the study. The two communal support variables (supervisory support and team support), two variables for work attitude (Organizational commitment and job satisfaction), three stress variables (role ambiguity, role conflict and work overload) and one variable of job outcome (turnover intention). Data was collected in April 2021. This data was 
Khan, S. (2021), “Communal support, work attitude, stress and job outcome across gender", Management and entrepreneurship: trends of development, 3(17), pp.18-26. Available at: https://doi.org/10.26661/2522-1566/2021-3/1702.

converted into useful information using SPSS (version 23). Data was analyzed Reliability test and correlation to draw useful conclusion.

\section{RESULT AND DISCUSSION}

In this section, the researcher will be discussing about the information collected. This section will through light on all the four variables and its sub variable. Objective of the research and hypothesis will also be discussed in this section. Conclusion will be draw based on the results.

Table 1

Gender of the respondents

\begin{tabular}{lllll}
\hline Sr. No. & Gender & Frequency & Percentage & Cumulative Percentage \\
\hline $\mathbf{1}$ & Male & 62 & 44.93 & 44.93 \\
$\mathbf{2}$ & Female & 76 & 55.07 & 100.00 \\
\hline
\end{tabular}

Source: Survey Result

Table above describes about the gender of the respondents. Majority of the respondents were female $(55.07 \%)$. It was observed that the IT sector is having more female employees than the male. The reason can be female employees are more sincere, hardworking and well qualified.

Reliability Test

\begin{tabular}{|c|c|c|c|}
\hline $\begin{array}{l}\text { Sr. } \\
\text { No. }\end{array}$ & Instrument & $\begin{array}{l}\text { No. of } \\
\text { Items }\end{array}$ & Cronbanch Alpha \\
\hline 1. & Supervisory Support & 3 & 0.829 \\
\hline 2. & Team Support & 4 & 0.681 \\
\hline 3. & Organizational Commitment & 4 & 0.723 \\
\hline 4. & Job Satisfaction & 26 & 0.891 \\
\hline 5. & Role Ambiguity & 4 & 0.621 \\
\hline 6. & Role Conflict & 3 & 0.733 \\
\hline 7. & Work Overload & 3 & 0.934 \\
\hline 8. & Turnover Intention & 3 & 0.859 \\
\hline
\end{tabular}

\section{Source: Outcome of Analysis of Data}

Table 2 is of Reliability test. Reliability of data indicates the consistency with which identical data can be generated by controlling the questionnaire repeatedly. Reliability is measured through Cronbach's alpha. This value should exceed 0.6. Table above is evident that all the values are well above 0.6 , suggesting that the data collected is very much reliable and all the statements used to measure the opinion of respondents about the respective constructs well explain these constructs with the excellent degree of internal consistency. 
Table 3

Matrix of Correlation of Variables

\begin{tabular}{|c|c|c|c|c|c|c|c|c|c|c|}
\hline Variables & $\sum_{\Sigma}^{\Xi}$ & $\hat{\varkappa}$ & 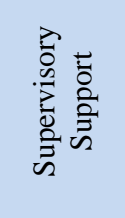 & 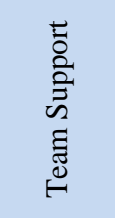 & 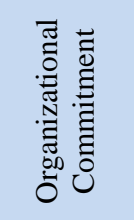 & 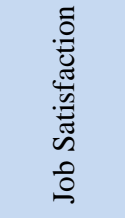 & 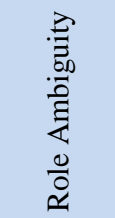 & 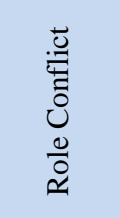 & 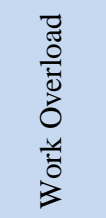 & 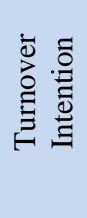 \\
\hline $\begin{array}{c}\text { Supervisory } \\
\text { Support }\end{array}$ & 3.9812 & 2.8091 & 1 & & & & & & & \\
\hline Team Support & 4.0601 & 2.9812 & 0.113 & 1 & & & & & & \\
\hline $\begin{array}{c}\text { Organizational } \\
\text { Commitment }\end{array}$ & 2.2108 & 2.6991 & $0.377 * *$ & $0.362 * *$ & 1 & & & & & \\
\hline Job Satisfaction & 3.4508 & 5.0891 & $0.458 * *$ & $0.387 * *$ & $0.431 * *$ & 1 & & & & \\
\hline Role Ambiguity & 5.6727 & 2.6578 & $0.351 * *$ & -0.349 & $0.211 * *$ & $0.301 * *$ & 1 & & & \\
\hline Role Conflict & 2.8795 & 3.1897 & -0.061 & $0.186 * *$ & $-0.177 * *$ & $-0.167 * *$ & $0.221 * *$ & 1 & & \\
\hline Work Overload & 3.1952 & 3.4679 & $-0.189 * *$ & 0.109 & $-0.166 * *$ & $-0,093$ & -0.029 & $0.173 * *$ & 1 & \\
\hline $\begin{array}{l}\text { Turnover } \\
\text { Intention }\end{array}$ & 2.4761 & 3.5634 & $-0.355^{* *} *$ & $\begin{array}{c}- \\
0,369 * *\end{array}$ & $-0.356^{* *}$ & $-0.521 * *$ & $\begin{array}{c}- \\
0.159 * *\end{array}$ & -0.000 & $\begin{array}{c}- \\
0.137 *\end{array}$ & 1 \\
\hline
\end{tabular}

**p,0.01 and *p,0.05

\section{Source: Outcome of Analysis of Data using SPSS}

Table 3 presents the result of correlation of Matrix. Above table reflects the correlation among the variables. It was quite surprising to find that role ambiguity and is positively and significantly related to organizational commitment and job satisfaction, and is negatively and significantly related to turnover intention. Other relations are very normal can be found in many literatures.

Table 4

$$
\text { T-Test }
$$

\begin{tabular}{|c|c|c|c|c|c|c|}
\hline \multicolumn{2}{|c|}{ Variable } & \multicolumn{2}{|c|}{ Female } & \multicolumn{2}{|c|}{ Male } & \multirow[b]{2}{*}{ T value } \\
\hline & & Mean & SD & Mean & SD & \\
\hline \multirow[t]{2}{*}{$\begin{array}{c}\text { Communal } \\
\text { Support }\end{array}$} & $\begin{array}{l}\text { Supervisory } \\
\text { Support }\end{array}$ & 12.9712 & 2.0612 & 11.5698 & 2.7801 & $-3.713 * *$ \\
\hline & Team Support & 16.9482 & 2.6185 & 16.1610 & 3.0891 & -0.399 \\
\hline \multirow[t]{2}{*}{$\begin{array}{c}\text { Work } \\
\text { Attitude }\end{array}$} & $\begin{array}{l}\text { Organizational } \\
\text { Commitment }\end{array}$ & 17.0459 & 2.6512 & 16.0681 & 2.8115 & -1.167 \\
\hline & $\begin{array}{l}\text { Job } \\
\text { Satisfaction }\end{array}$ & 119.0729 & 3.6501 & 118.6916 & 3.3781 & -0.659 \\
\hline \multirow[t]{3}{*}{ Stress } & $\begin{array}{l}\text { Role } \\
\text { Ambiguity }\end{array}$ & 18.0141 & 2.1314 & 16.5642 & 2.8720 & $-2.341 *$ \\
\hline & Role Conflict & 8.3109 & 3.0715 & 8.7979 & 3.0557 & 1.175 \\
\hline & $\begin{array}{l}\text { Work } \\
\text { Overload }\end{array}$ & 8.9859 & 3.9156 & 8.8744 & 3.4237 & 1.241 \\
\hline $\begin{array}{c}\text { Job } \\
\text { Outcome }\end{array}$ & $\begin{array}{l}\text { Turnover } \\
\text { Intention }\end{array}$ & 6.7891 & 3.3945 & 7.8857 & 3.6726 & 1.569 \\
\hline
\end{tabular}


Khan, S. (2021), "Communal support, work attitude, stress and job outcome across gender", Management and entrepreneurship: trends of development, 3(17), pp.18-26. Available at: https://doi.org/10.26661/2522-1566/2021-3/1702.

Above table depicts the t- test to find the significance difference between the gender groups in terms of variables of communal support, work attitude, stress and job outcome. Table is evident that supervisory support is higher in case of female then male. As far as team support, organizational commitment, job satisfaction and turnover intention is concerned, it was found no significant difference between female and male groups. Role ambiguity was found to be higher in female group. No significant difference was found between female and male groups in case of role conflict and work overload.

Based on above discussion, researcher partial accept the $\mathrm{H}_{1}$ hypothesis as supervisory support is higher for females than male and no significant difference was found between gender and team support. $\mathrm{H}_{2}$ is rejected as no significant difference was found between male and female employees for work attitude. $\mathrm{H}_{3}$ is partially accepted. Role ambiguity is higher for females and no gender difference was found in case of role conflict and work overload. $\mathrm{H}_{4}$ is rejected as job outcome is same for male and female.

Male and female are two different assets to the organization. There is a possibility that some jobs are done well by male and some tasks are executed perfectly by females. Each gender has its own style of performing his duty. Hence an interesting work was executed in a female dominant service sector to understand gender difference on four selected variables. Based on the objective hypothesis were also discussed.

This research tried to explore the gender difference on 4 selected variables i.e., communal support, work attitude, stress and job outcome across gender. To arrive to a conclusion, researcher has first done reliability test to check the reliability of the variable. All variables have passed a minimum value of 0.6 (Nannally, 1978). Correlation of variables was done and finally $\mathrm{T}$ test was conducted. Based on the results conclusions were drawn.

\section{CONCLUSION}

The researcher has carried out this research to know the difference between female and male employees working in IT sector. The variables used for this study are communal support, work attitude, stress and job outcome. Past studies have concluded that support from the team, work attitude and job outcome have difference with respect to gender. However, the result of this study contradicts it and concludes that, there is no gender difference in terms on team support, work attitudes, and job outcome. It is also concluded that equal opportunities (as no significant manual work in involved for both, men and women) are provided for men and women in the information technology industry. This also depends on a person's cognitive abilities, and there is no cognitive gender difference among IT professionals. Organizational attitudes are hospitable to professional women in terms of rewards and recognition, allocation of resource, and quality of work life. This is reflected in women's experience of getting more communal support. The discovery of differences in explanatory variables, such as role ambiguity between surveyed men and women, confirms early research on gender differences. It is because women need to work hard and repeatedly perform better than others to demonstrate their credibility, so it is higher in case of female employees. This research contradicts previous researches on gender differences in supervisor support. It was found that female get good supervisory support than male. As far as variables of stress (role conflict and work-overload) is concerned, researcher did find any significant difference between male and female.

\section{REFERENCES}

Andrade, M. S. Westover, J. H. and Peterson, J. (2019), “Job Satisfaction and Gender", Journal of Business Diversity, Vol. 19, Issue 3, p 22. Available at: https://www.emerald.com/insight/content/doi/10.1108/ (Accessed 10.05.2021), (in English). 
Anitei, M. Chraif, M. and Ionita, E. (2015), "Gender differences in workload and self-perceived burnout in a multinational company from Bucharest", Procedia - Social and Behavioral Sciences, $\quad$ Vol. $187, \quad$ p $733 . \quad$ Available at: https://www.researchgate.net/publication/327932378_(Accessed 10.05.2021), (in English).

Boles, J.S. Wood, J.A. and Johnson, J. (2003), "Interrelationships of Role Conflict, Role Ambiguity, and Work-Family Conflict with Different Facets of Job Satisfaction and the Moderating Effects of Gender", The Journal of Personal Selling and Sales Management. Vol. 23, Issue 2, p 99. Available at: https://www.tandfonline.com/doi/abs/10.1080/08853134.2003.10748991 (Accessed 10.05.2021), (in English).

Boucher, A. and Cerna, L. (2014), "Current Policy Trends in Skilled Immigration Policy", International Migration, Vol. 52, $\mathrm{p}$ 21. Available at: https://onlinelibrary.wiley.com/doi/10.1111/imig.12152 (Accessed 10.05.2021), (in English).

Dhanalakshmi, K. Kathiravan, C. and Muthukumar, N. (2019), "A Study on Work Stress Among Employees and Its Impact on Employee Performance in BPO Hyderabad", Journal of the Gujarat Research Society. Vol. 21, Issue 15s2, p 51. Available at: https://www.researchgate.net/publication/343064639 (Accessed 10.05.2021), (in English).

Gibbons, J., Wilson, S. L. and Rufener, C. A. (2006), "Gender Attitudes Mediate Gender Differences in Attitudes Toward Adoption in Guatemala", Sex Roles, Vol. 54, Issue 1/2, p 139. Available at: https://doi.org/10.1007/s11199-005-8875-0

Hindes, Y. L. and Andrews, J. W. (2011), "Influence of Gender on the Supervisory Relationship: A Review of the Empirical Research from 1996 to 2010", Canadian Journal of Counselling and Psychotherapy, Vol. 45, Issue 3, p 240. Available at: https://dev.journalhosting.ucalgary.ca/index.php/rcc/article/view/59318 (Accessed 10.05.2021), (in English).

Huwang, H. and Kim, M. J. (2017), "Relationship of Gender Role Conflict and Job Satisfaction to Turnover Intention for Men in Nursing, Journal of Korean Academy of Nursing Administration, Vol. 23, Issue 1, p 32. Available at: https://doi.org/10.11111/jkana.2017.23.1.32

Khalid, S.A., Jusoff K., Ali, H., Ismaeil, M., Kassim, K. M., and Rehman, N. A (2009), "Gender as a Moderator of the Relationship between OCB and Turnover Intention", Asian Social Science. Vol. 5, Issue 6, p 108. Available at: https://d1wqtxts1xzle7.cloudfront.net/ (Accessed 10.05.2021), (in English).

Khan, S. I and Abdullah, N. (2019), "The Effect of ATM Service Quality on Consumer Satisfaction and Loyalty: An Empirical Analysis", Russian Journal of Agricultural and Socio-Economic Sciences, Vol. 5, Issue 89, p 227. Available at: https://doi.org/10.18551/rjoas.2019-05.28

Kokubun, K. and Yasui, M. (2021), "Gender differences in organizational commitment and rewards within Japanese manufacturing companies in China", Cross Cultural \& Strategic Management, Vol. 28, Issue 3, p 501. Available at: https://doi.org/10.1108/ccsm-06-20190119

Narayan, R. (2014). Organizational role stress in relationship with social support among industrial employees. International Journal of Exclusive Management Research. Vol. 2, Issue 2, p 148. Available at: https://www.researchgate.net/publication/235258105 (Accessed 10.05.2021), (in English).

Prathyusha, B. Durgaprasad, C. H. S., and Reddy, P. S. (2015), "Professional Life Stress among Software Professionals in Hyderabad - An Evaluation", International Journal of Innovative Research in Science, Engineering and Technology, Vol. 4, Issue 12, p 12371. Available at: https://doi.org/10.15680/IJIRSET.2015.0412131 
Khan, S. (2021), “Communal support, work attitude, stress and job outcome across gender", Management and entrepreneurship: trends of development, 3(17), pp.18-26. Available at: https://doi.org/10.26661/2522-1566/2021-3/1702.

Raghuram, P. Herman, C. Ben R. E. and Sondhi, G. (2018). "Women and IT Scorecard - India 2018". Available at: https://www.researchgate.net/publication/328603083_ (Accessed 10.05.2021), (in English).

Sabastian, V. (2013), "Gender differences in the attitudes towards work among young students. Cognitive and motivational features", Procedia - Social and Behavioral Sciences. Vol. 78, p 551. Available at: https://doi.org/10.1016/j.sbspro.2013.04.349

Sarkar, S. and Reddy, S. (2006), "U.S offshoring of Jobs and Businesses to India: A survey and Analysis", International Business \& Economics Research Journal, Vol. 5, Issue 7, p 45. Available at: https://doi.org/10.19030/iber.v5i7.3491

Sell, J. Griffith, W. I., and Wilson, R. K. (1998), "Are women more cooperative than men in social dilemmas?" Social Psychology Quarterly, Vol. 56, Issue 3, p 211. Available at: https://doi.org/10.2307/2786779

Sohail, I. K. and Dhuha, S. I. (2020), "A Study of Emotional Competence of Education, Telecommunication and Hospital Sector Employees in India", Journal of Xi'an University of Architecture \& Technology, Vol. XII, Issue III, p 5223. Available at: http://www.xajzkjdx.cn/gallery/488-mar2020.pdf (Accessed 10.05.2021), (in English).

Thomas, V., Krishna, Y. S., and Kumar, K. J. K. (2019), "Study on stress among software professionals in Madhapur area of Hyderabad, Telangana", International Journal of Community Medicine and Public Health, Vol. 6, Issue 9, p 4062. Available at: https://doi.org/10.18203/2394-6040.ijcmph20194017

Zainul, N. Zawawi, D., Aziz, A.Y., and Ali, M. H. (2020), "Work-Family Conflict and Job Performance: Moderating Effect of Social Support Among Employees in Malaysian Service Sector", International Journal of Business and Society, Vol. 21, Issue 1, p 79. Available at: https://doi.org/10.33736/ijbs.3224.2020

\title{
ВПЛИВ ГЕНДЕРУ НА КОЛЕКТИВНУ ПІДТРИМКУ, ВІДНОШЕННЯ ДО РОБОТИ, СТРЕСИ ТА РЕЗУЛЬТАТИ РОБОТИ
}

\author{
Sohail Imran Khan \\ Lebanese French University, \\ Erbil-Iraq
}

\begin{abstract}
Метою дослідження є вивчення розбіжностей між чоловіками та жінками IT службовцями за чотирма параметрами, а саме: коллективна підтримка, відношення до роботи, стрес та результат роботи. Ці чотири варіанти були поділені досліджені з точки зору наступних складових: колективна підтримка (супервізія та командна підтримка), відношення до роботи (привілейована організація та задоволення робочої роботи), стреси (невизначеність ролей, конфліктні ролі та робоча перегрузка) та результати роботи (намір зміни кадрів). У минулих дослідженнях, пов'язаних з суспільною підтримкою, ставленням до роботи, стресом та результатами роботи, дослідження проводилися індивідуально, але практично не проводилось вивчення взаємовідносин, особливо у відношенні поля. У дослідженнях прийняли участь 138 IT-співробітників. Дані пропозиції були проаналізовані за допомогою програмного забезпечення SPSS, щоб зробити висновок. Були сформовані 4 гіпотези, деякі були частково прийняті та потребують подальшого дослідження. Висновки показали, що жінки мають більш високу степінь супервізії та неоднозначну роль. 3 іншого боку, підтримка команд, організаційна привілейованість, задоволеність роботою, рольовий конфлікт, робоча перегрузка не істотно вирізняються виходячи з полу.
\end{abstract}

Ключові слова: суспільна підтримка, підтримка команди, прихильність організації, задоволеність роботою, двозначність ролі, конфлікт ролей, перевантаження роботою, плинність. 


\title{
ВЛИЯНИЕ ГЕНДЕРА НА КОЛЛЕКТИВНОЙ ПОДДЕРЖКУ, ОТНОШЕНИЕ К РАБОТЕ, СТРЕССЫ И РЕЗУЛЬТАТЫ РАБОТЫ
}

\author{
Sohail Imran Khan \\ Lebanese French University, \\ Erbil-Iraq
}

\begin{abstract}
Цель исследования - изучить разницу между мужчинами и женщинами ИТ-служащими по четырем параметрам, а именно: коллективная поддержка, отношение к работе, стресс и результат работы. Эти четыре переменные были далее разделены на составляющие: коллективная поддержка (супервизия и командная поддержка), отношение к работе (приверженность организации и удовлетворенность работой), стресс (неопределенность ролей, конфликт ролей и рабочая перегрузка) и результат работы (намерение смены кадров). В прошлых исследованиях, связанных с общественной поддержкой, отношением к работе, стрессом и результатами работы, проводились индивидуально, практически не уделялось внимание изучению взаимоотношений между сотрудниками, особенно в отношении пола. В исследовании приняли участие 138 ИТ-сотрудников. Данные опроса были проанализированы с помощью программного обеспечения SPSS, чтобы сделать итоговый вывод. Были сформулированы 4 гипотезы, некоторые были частично приняты и нуждаются в дальнейшем исследовании. Выводы заключаются в том, что женщины имеют более высокую степень супервизии и неоднозначностью ролей. С другой стороны, поддержка команды, организационная приверженность, удовлетворенность работой, ролевой конфликт, рабочая перегрузка и намерение смены персонала не имели существенных различий по признаку пола.
\end{abstract}

Ключевые слова: общественная поддержка, поддержка команды, приверженность организации, удовлетворенность работой, двусмысленность роли, конфликт ролей, перегрузки работой, текучесть 